\title{
A model of propagating waves in cerebral cortex across network states
}

\author{
Lyle E Muller II, Alain Destexhe \\ From Twentieth Annual Computational Neuroscience Meeting: CNS*2011 \\ Stockholm, Sweden. 23-28 July 2011
}

Propagating waves of activity have been measured in cerebral cortex in various experimental preparations, and show different propagation speed or patterns. Using network models, we investigated whether the "state" of the network can explain these differences. We used a modified version of a previous model, in which neuronal adaptation can facilitate the transition from activated, asynchronous irregular (AI) states to quiescence in random networks. [1] With a proper re-ignition mechanism, these networks can transition between UP/DOWN and AI states with different levels of adaptation. Here, we have studied the occurrence of propagating waves during this transition from UP/DOWN to self-sustained activated states in topographic spiking neural network models and compared these results to voltage-sensitive dye imaging data from the visual cortex, as well as to other known experimental results. The addition of local connections with realistic synaptic delays in these topographic spiking neural network models allows for the possibility of propagating slow waves in some network states. Further, while it is generally thought that the large, low-frequency propagation evoked by sensory stimulation during heavily anesthetized states gives way to a bump attractor during waking, activated states, we demonstrate the possibility that propagating activity exists throughout the whole spectrum of network activation and shifts from low frequency (predominantly controlled by adaptation) to high frequency (predominantly controlled by E/I interactions) as the level of network activation increases. With these results from network modeling, we aim to account both for observed effects of anesthesia on the spread of cortical activity in voltage-sensitive dye and electrophysiological experiments

\footnotetext{
* Correspondence: muller@inaf.cnrs-gif.fr
} UNIC, CNRS, Gif-sur-Yvette, 91198, France
[2-4] and for the observation of traveling high-frequency oscillations in vitro [5] and in awake monkeys [6,7].

Published: 18 July 2011

\section{References}

1. Destexhe A: Self-sustained asynchronous irregular states and Up-Down states in thalamic, cortical and thalamocortical networks of nonlinear integrate-andfire neurons. Journal of Computational Neuroscience 2009, 27:493-506.

2. Ferezou I, Bolea S, Petersen CCH: Visualizing the Cortical Representation of Whisker Touch: Voltage-Sensitive Dye Imaging in Freely Moving Mice. Neuron 2006, 50:617-629.

3. Nauhaus I, Busse L, Carandini M, Ringach DL: Stimulus contrast modulates functional connectivity in visual cortex. Nat Neurosci 2008, 12:70-76.

4. Mohajerani MH, McVea DA, Fingas M, Murphy TH: Mirrored Bilateral SlowWave Cortical Activity within Local Circuits Revealed by Fast

Bihemispheric Voltage-Sensitive Dye Imaging in Anesthetized and Awake Mice. J Neurosci 2010, 30:3745-3751.

5. Metherate $\mathrm{R}$, Cruikshank SJ: Thalamocortical inputs trigger a propagating envelope of gamma-band activity in auditory cortex in vitro. Exp Brain Res 1999, 126:160-174.

6. Rubino D, Robbins KA, Hatsopoulos NG: Propagating waves mediate information transfer in the motor cortex. Nat Neurosci 2006, 9:1549-1557.

7. Gabriel A, Eckhorn R: A multi-channel correlation method detects traveling gamma-waves in monkey visual cortex. J Neurosci Methods 2003, 131:171-184.

doi:10.1186/1471-2202-12-S1-P67

Cite this article as: Muller and Destexhe: A model of propagating waves in cerebral cortex across network states. BMC Neuroscience 2011 12(Suppl 1):P67.

Submit your next manuscript to BioMed Central and take full advantage of:

- Convenient online submission

- Thorough peer review

- No space constraints or color figure charges

- Immediate publication on acceptance

- Inclusion in PubMed, CAS, Scopus and Google Scholar

- Research which is freely available for redistribution
C Biomed Central

(c) 2011 Muller and Destexhe; licensee BioMed Central Ltd. This is an open access article distributed under the terms of the Creative Commons Attribution License (http://creativecommons.org/licenses/by/2.0), which permits unrestricted use, distribution, and reproduction in any medium, provided the original work is properly cited. 